\title{
Alternative environmentalities: recasting the assessment of Canada's first Marine Stewardship Council-certified fishery in social terms
}

\author{
$\underline{\text { Paul Foley }}^{1}$, Dinah A. Okvere ${ }^{2}$ and Charles Mather ${ }^{3}$
}

\begin{abstract}
We use a Foucault-inspired environmentalities analytical lens to conceptualize alternative sustainability auditing frameworks. The Marine Stewardship Council (MSC) claims to administer the international gold standard for sustainability evaluation of fisheries, yet the livelihoods of many people who depend on Canada's first MSC-certified fishery are in serious jeopardy. After decades of growth that helped fishers and coastal communities alleviate the social consequences of the infamous cod collapse, the northern shrimp fishery in eastern Canada is experiencing ecological change and social conflict over the distribution of quota reductions. However, recent disputes over the distribution, and social consequences, of quota reductions in this fishery are completely invisible in assessment and auditing documents for the successful recertification of the fishery to the MSC's standard for "sustainable and well managed fisheries" in 2016. We draw upon aspects of an alternative assessment framework to highlight information and knowledge that a socially attentive sustainability audit of this fishery might consider. The alternative auditing framework renders visible social dimensions of Canada's northern shrimp fishery, including government decision making that incorporates ethical and moral economy principles, the distribution of access to various interests, uses of access benefits for regional and community development purposes, and conflict over policy and resource access during a period of resource decline and dispossession. Although the spread of auditing frameworks across natural resource sectors tends to reinforce neoliberal interests and undermine social justice aims, we argue that the development of alternative assessment frameworks that clearly make visible materialist social development relationship and knowledge can enable action in support of social justice objectives.
\end{abstract}

Key Words: assessment frameworks; audits; environmentality; governmentality; Marine Stewardship Council; sustainability

\section{INTRODUCTION}

We have reached a crisis. This is D-Day... This is the final frontier... If we thought the cod moratorium was tough on people and communities, I can't imagine what this will be... It will pale in comparison. We do not have another fishery to turn to... We could see the closure of four, five shrimp plants here in Newfoundland. That's catastrophic for Newfoundland and outport communities. - General manager of the Fogo Island Cooperative Society (hereafter Fogo Island Co-op), as quoted in Ensing (2016).

At the heart of this struggle... is how we share our fisheries resources and who benefits from them. - Atlantic director of the national trade union Unifor, as quoted in CBC News (2016).

This is about the survival of our communities. - Inshore director of the Fish, Food and Allied Workers (FFAW)Unifor union, as quoted in CBC News (2016).

The context for the crisis facing the Fogo Island Co-op and the Fish, Food and Allied Workers-Unifor union, representing thousands of inshore fish harvesters and processing plant works in Newfoundland and Labrador (NL), was the recent change in the health of Atlantic Canada's northern shrimp stocks, and subsequent decisions to cut quotas dramatically for northern shrimp for inshore and offshore interests in the multisector fishery. From the perspective of inshore fishery interests, including those with the Fogo Island Co-op and FFAW-Unifor union, quota cuts were biased in favor of the offshore sector of large factory freezer trawlers, which received proportionately fewer cuts because of the application by Fisheries and Oceans Canada (DFO) of a "last in, first out" (LIFO) policy on resource withdrawal; because the inshore allocations were generally authorized more recently, the LIFO policy served to protect the offshore allocations disproportionately. The LIFO policy came under significant scrutiny and was the focus of intense political pressure, particularly in NL's inshore sector. Whereas inshore interests generally called on DFO to prioritize the inshore owner-operator sector instead of the generally more corporate offshore factory freezer trawler sector in quota allocations, organized interests in the offshore sector mobilized their own information campaign, arguing that hundreds of people in NL benefit from the offshore fishery through year-round, high-paying jobs (CBC News 2016). The conflict over LIFO as a means of quota reductions pitted inshore interests against offshore interests, with competing claims for which sector and type of production generated better economic development outcomes for people and communities.

These conflicts coincided with the recertification of the northern shrimp fishery as "sustainable and well managed" by the Marine Stewardship Council (MSC). In 2016, just a few months after police were called when inshore sector shrimp fishermen smashed a window and forced their way into DFO regional headquarters in NL to protest against expected further quota cuts (Bartlett and Kelland 2017), a third-party certification company announced the recertification of the northern shrimp fishery to the MSC's environmental standard, with certification valid for 5 years subject to meeting conditions at subsequent annual surveillance audits (Powles et al. 2016). A decade after the original assessment that made northern shrimp the first Canadian fishery certified by the MSC (Foley 2012, Foley and McCay 2014), the recent assessment for recertification identifies abstract stock

${ }^{1}$ Environmental Policy Institute, School of Science and the Environment, Memorial University of Newfoundland (Grenfell Campus), ${ }^{2}$ School of Science and the Environment, Memorial University of Newfoundland (Grenfell Campus), ${ }^{3}$ Department of Geography, Memorial University of Newfoundland, St John's 
assessments, aggregate declines in stock abundance, and reductions in overall total allowable catches, but neglects to include information and indicators on social relations of production, the distributive characteristics of quota allocations and reductions, and the social development consequences of recent ecological and management dynamics. The social struggles and policy disputes over quota distribution arrangements, relative reductions among fleets, and disputes over allocation policy were completely absent from the extensive third-party assessment report that evaluated the fishery against the MSC's standard (Powles et al. 2016). Also missing was any reference to the thousands of individuals and dozens of rural and remote coastal communities whose sustainability is enhanced by the employment and related economic and social development benefits of the northern shrimp fishery. Because the MSC's sustainability standard does not require assessors to include considerations of social development dimensions of fisheries, such omissions are not surprising. However, even if the assessment and certification is procedurally and technically sound with respect to the MSC's environmental standard, ignoring or discounting information on the ongoing social conflict and dispossession in the fishery raises questions about substantive transparency and the MSC's fundamental understanding of "sustainable and well managed."

The northern shrimp fishery, therefore, highlights a general problem of social development questions facing the MSC and, more broadly, the sustainable seafood movement, which is increasingly considering the challenge of integrating social considerations into sustainability assessments (Kittinger et al. 2017). Like government fisheries policy and management (Urquhart et al. 2013, Stephenson et al. 2018b), the MSC and the sustainable seafood movement has, to date, largely focused on the conservation of fish stocks and marine environments, sidelining social issues such as allocation distribution, labor rights, and health and safety conditions (Ponte 2008, Potts et al. 2016). The MSC thus reinforces the longstanding issue of exclusion of social considerations in questions of fisheries management and sustainability (Symes and Phillipson 2009, Stephenson et al. 2018b). Drawing on the case of the northern shrimp fishery, we ask: What types of social development knowledge might be considered in a more holistic social-ecological sustainability assessment?

To guide our empirical analysis, we draw on a full-spectrum sustainability assessment framework developed by the Canadian Fisheries Research Network to highlight social considerations (Stephenson et al. 2018b). Theoretically, we suggest that this alternative assessment framework can be understood as a "technology of government" guided by a particular environmentality, a concept adapted from the notion of governmentality developed by Foucault (2008). The governmentality approach sensitizes us to alternative rationalities that can inform the development of auditing frameworks. Such assessment frameworks are reflective of particular rationalities that tend to support neoliberal agendas. However, rather than dismiss auditing as a political tool only for neoliberal interests and agendas, we seek to contribute to the development of an alternative environmentality (Fletcher 2010), including technologies of government supportive of sustainable and socially just development. Such an alternative environmentality emphasizes social dimensions and social struggles of development that are often obscured by the narrowly conservation-oriented and arguably neoliberal environmentality of governance initiatives like the MSC. In this way, we seek to contribute to the development of what might be understood as a social-ecological environmentality for sustainability evaluation. We next describe the theoretical perspective applied in the study. We then introduce the methods and describe why the Canadian Fisheries Research Network's sustainability assessment framework is used to analyze the northern shrimp fishery. We end with a discussion and conclusion.

\section{POLITICAL ECOLOGY OF AUDIT ENVIRONMENTALITIES}

We draw on the Foucault-inspired literature on governmentality to frame our analysis of audits and assessments. Governmentality, for our purposes, is understood to constitute part of the process whereby authority is increasingly exerted, not through direct government coercion, but rather through new disciplinary mechanisms of expertise and techniques that make possible "government at a distance." Following Djama et al. (2011:189), we note the significance of "political rationalities" and "technologies of government" as analytical dimensions of governmentality that are useful to the study of auditing frameworks. Political rationality refers to the ideas and knowledge that frame an object of government such as fisheries, whereas technologies of government refer to the tools and tactics used to govern such as auditing frameworks (Djama et al. 2011). Sustainability assessment frameworks, from private certification standards to government-led assessment frameworks and academic-led evaluation initiatives, can be interpreted as part of a more general international circulation of values, knowledge, and audit-based technologies of the political rationality of managerialism (Djama et al. 2011). Technologies of government such as auditing, assessment frameworks, and benchmarking linked to a managerial rationality have the sometimes intended and sometimes unintended effect of obscuring conflicts and politics in sustainability standards (Djama et al. 2011, Parlee 2016).

Most of the literature on governmentality is unequivocally critical of audits as driven by and reinforcing neoliberal agendas. Research has shown how the spread of "audit culture" across organizations in sectors from finance to the military has resulted in negative consequences such as loss of organizational trust, practices of gaming the auditing processes, a reductionist preoccupation with inordinately expensive compliance practices, a culture of blamism focusing on short-term objectives, and a tendency to focus on what is counted to the exclusion of what cannot be counted (Shore and Wright 2015). In addition to intraorganizational auditing, third-party audit-based assessment standards and certifications have been analyzed as a specifically neoliberal form of governmentality (Hughes 2001). The "ethical audit regime" created through the proliferation of social and environmental audits in the global economy legitimizes neoliberal approaches to environmental and social governance in corporatedominated global supply chains (LeBaron and Lister 2015, LeBaron et al. 2017). As Wood (2012) argues in a context of international standards, standardization tends to render invisible the people, places, knowledge, practices, values, and activities that do not conform to the dominant development project of global capitalism. We share this critical perspective on audits as 
inherently political, not neutral, processes of governance that tend to reinforce status quo relations and institutions of power. However, rather than paint the global spread of audit culture as a necessarily neoliberal phenomenon, we highlight the variations in manifestations and objectives of audit culture and the coexistence of numerous audit agendas (Jensen and Winthereik 2013). Here, we seek to highlight forms of auditing that render visible the types of social information that a narrowly conservation-focused audit renders invisible.

To highlight the multiple objectives manifesting in audit culture, we follow Fletcher (2010) to explore the potential for a distinctive social justice-oriented environmentality in the governance of natural resources. Although the concept of environmentality as developed by Agrawal (2005) emphasizes particular knowledge, institutional design, and subject formation through the application of technologies of governance in situations of decentralization and community-based management, we are more interested in the question of for whom environmentality is formed. Highlighting the value of democratization themes in Elinor Ostrom and colleagues' (Ostrom 1990, Ostrom et al. 1999) common property regime analysis in articulating alternatives to Hardin's (1968) "tragedy of the commons" thesis, Fletcher (2010:179) suggests, "In engaging with the conservation debate, therefore, it might be useful for political ecologists to more explicitly frame their interventions in terms of the specific environmentality or environmentalities they wish to endorse and to clearly contrast this vision with the very different arts of environmental government expressed in the conservation models they oppose." In other words, the notion of alternative environmentalities can be used to shed light on "contrasting strategies of governing both natural resources and their human users that compete to define appropriate resource management within any given context" (Fletcher 2010:179). Although Agrawal's (2005) original formulation does not focus on material questions, he also recognizes the potential for an alternative environmentality that moves beyond narrow goals of economic efficiency to include community needs and aspirations. Indeed, one strategy to reduce the risks of audit culture is to create alternative experts and systems of evaluation, including changing the focus on what counts to include not just economy and efficiency but also social considerations such as well-being and quality of life (Shore and Wright 2015). In this context, we seek to test the conceptual framework of alternative environmentalities empirically by engaging particular conservation debates in particular resource management contexts.

The empirical basis for what we are conceptualizing as a socialecological environmentality was inspired by the Canadian Fisheries Research Network's (CFRN) Project 1.1 - Enhanced fisheries knowledge for an evolving management regime (Stephenson et al. 2018b). The project group, including the lead author of this paper, sought to develop a comprehensive or integrated framework for fishery evaluation that included social, economic, and institutional considerations, as well as ecological considerations. As part of the process, the group defined sustainable fisheries as such: "A sustainable fishery respects the ecological integrity of the ocean and its resources; is ethical, responsibly governed, economically viable and technologically appropriate; supports communities; draws on local culture, heritage, and diverse knowledge systems; and enhances health, wellbeing and the public good" (Stephenson et al. 2018b:11).

The team then developed a framework around this particular social-ecological rationality, including elements and candidate objectives from Canadian policy and international agreements to which Canada has committed (Stephenson et al. 2018a). By actively fostering socially attentive rationalities and technologies of government, the CFRN framework contributes to a proliferation of environmentalities in fisheries governance. From a multiple environmentalities perspective (Fletcher 2017), we are able to contrast a narrowly conservation-oriented environmentality of the MSC, which is widely critiqued as excluding social considerations and legitimizing neoliberal order (Ponte 2008, 2009, Konefal 2013, Parlee and Wiber 2014), with what we understand as a social-ecological environmentality that better reflects social dimensions of fisheries management problems.

\section{METHODS}

The research project on northern shrimp developed as one of the case studies within the CFRN's Project 1.1. Case studies from a variety of Canadian fisheries were selected to inform the development of the framework and to test its application. Canada's northern shrimp fishery was identified by industry partners, particularly the FFAW-Unifor, as a suitable fishery for the study. Using existing literature, industry data, and $>60$ key informant interviews focusing on several regions that depend socioeconomically on the northern shrimp fishery, the research identified the evolution, implementation, and effects of social objectives in the northern shrimp fishery, with a focus on regional development outcomes in four areas of Newfoundland and Labrador since the 1970s (Foley et al. 2013, 2015, Foley and Mather 2016, 2018, Foley et al. 2017). While the development impacts of the northern shrimp fishery are complex and span from southern regions of Nova Scotia to Inuit communities in Nunavut and Nunavik, our research focused on developing fieldwork-informed empirical studies of Fogo Island, the northern tip of Newfoundland's Northern Peninsula, southeast Labrador, and northern Labrador/Nunatsiavut (Fig. 1).

We examined the northern shrimp regional case studies with reference to the following elements of CFRN's sustainability assessment framework (Stephenson et al. 2018a): distribution of access and benefits, regional economic benefits to community, and sustainable livelihoods. Although our fieldwork for studying the northern shrimp fishery was completed before the CFRN framework was finalized, the data gathered during the fieldwork, which focused on the relationship between social objectives in fisheries policy and regional development outcomes, aligned well with these categories of elements. Here, we draw upon published synthesis findings and secondary literature to reanalyze these social development elements through three major periods of social-ecological change: (1) an initial period of enclosure and Canadianization of the fishery through the development of an offshore sector, (2) an expansionary period that included the development of an inshore fishing and processing sector, and (3) a period of resource contraction and social dispossession. 
Fig. 1. Map indicating the locations of the case study regions within the province of Newfoundland and Labrador, Canada.

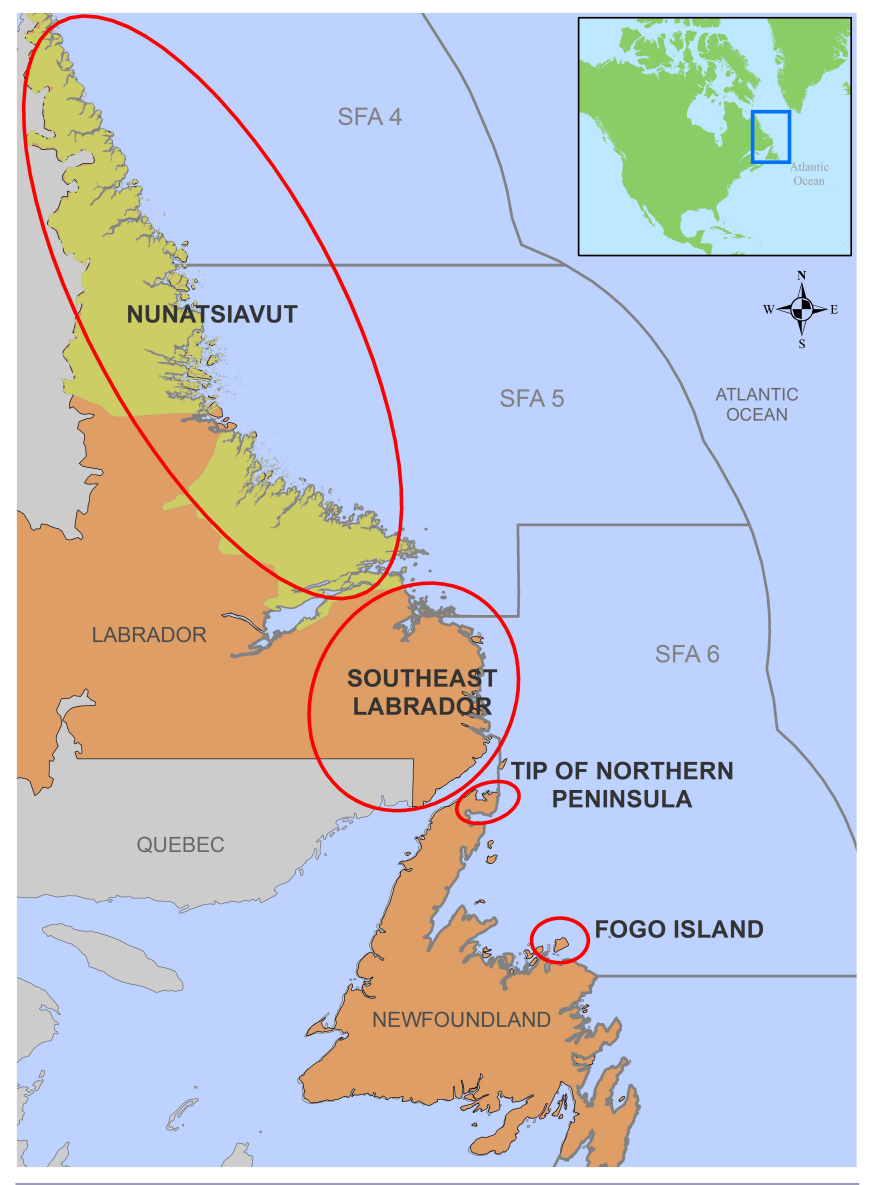

\section{FINDINGS}

Developmental phase 1: enclosure and Canadianization, 1978 to early 1990s

Distribution of access and benefits

Canada's northern shrimp fishery has always been shaped by ethical and moral economy principles of distribution of access and benefits. It emerged in the wake of the global enclosure movement and the Government of Canada's 1977 declaration of its 200-mile $(322 \mathrm{~km})$ limit that cut off formal open access to vessels owned by northern European interests that previously fished northern shrimp under open-access conditions in the areas off eastern Canada. Although the Government of Canada's allocation policies for northern shrimp aimed to "Canadianize" the previously international fishery, two specific distributive principles influenced early allocations: a principle of geographic distribution of offshore licences across Atlantic Canadian provinces and territories, and a preference for enhancing development for rural and remote coastal peoples living adjacent to offshore resources through cooperatives or communityembedded companies (Foley et al. 2015). Although allocation decisions were guided by general ethical considerations (Foley and Mather 2016), the actual distributions were not without controversy, and inevitable exclusions occurred as some interests, coastal communities, and regions benefited more than others. Nevertheless, both principles of distribution were in turn shaped by the notion of adjacency rights, the idea that groups living in coastal regions adjacent to marine resources ought to benefit from the development of those resources. The principle of adjacency was subsequently institutionalized as a Department of Fisheries and Oceans (DFO) policy for this fishery by the 1990s (Foley and Mather 2018).

\section{Regional economic benefits to communities}

Although many fisheries management agencies have developed policies based on neoliberal economic principles that privilege commodified access rights through individual transferable quotas, the legitimation of social purpose organizations in the early history of northern shrimp allocation policy illustrates the potential for social-ecological rationalities in fisheries management. Community and regional economic benefits were not automatically derived from simple allocations of a quantity of shrimp quota, but depended on several factors linked to specific social relations and principles of production. These included DFO's allocation of quota to community-based organizations with their own distributive decision-making mandates, the presence of productive inshore fishing and processing infrastructure and activities, and a policy environment supporting an independent owner-operator fleet of fishers (Foley et al. 2015).

Two of our case studies can be highlighted to illustrate the translation of allocations of quota into regional benefits through specific social and institutional relations of production. The Torngat Fish Producers Co-operative Society Limited (hereafter Torngat Co-op) has held an offshore license since 1980 to support fishery development in northern Labrador coastal communities from Nain to Rigolet. Using its newly acquired licenses and associated quotas as leverage, Torngat Co-op secured royalties from owners of southern offshore vessels who were interested in catching its quotas. Rather than take on the financial obligations and risk of owning and operating a large-scale trawler, royalty charters generated an infusion of cash that enabled Torngat Coop to invest in inshore fishery development. Although several fishprocessing operations have faltered over nearly four decades of operation, Torngat Co-op continues to use this royalty model to cross-subsidize an Arctic char plant in Nain and a turbot and crab plant in Makkovik (Foley et al. 2017). Total revenue since 1980 is estimated at $>$ CAD $\$ 32$ million, which has been mainly reinvested into the inshore fishing and processing infrastructure, operations, and labor (Torngat Co-op 2016). Royalties have also been invested in broader social and community development initiatives (Foley et al. 2017). Our second case study, the Labrador Fishermen's Union Shrimp Company Ltd. (hereafter Labrador Shrimp Company), was created in 1978 by inshore harvesters from the L'Anse aux Clair to Cartwright region of southeast Labrador to apply for and manage two offshore shrimp licenses. It was initially created as a cooperative but subsequently restructured as a company based on cooperative ownership and democratic decision-making principles. The Labrador Shrimp Company, like the Torngat Co-op, used a royalty charter model to generate revenue from its two licenses. It used this revenue to diversify and 
support inshore fisheries development through investments in processing facilities such as by purchasing processing plants in Cartwright and Mary's Harbour. By 2016, the Labrador Shrimp Company had invested CAD \$15 million into the construction of new plants and infrastructure renovations (Labrador Shrimp Company 2016). Processing plants have provided a particularly important development anchor where inshore fish harvesters land and sell their catch and where local residents, particularly women, find employment in processing and preparing seafood for export.

Overall, the two cases illustrate that distributing northern shrimp allocations to community-based organizations with institutional mandates to support community and regional development and to support inshore fishing and processing plant development was an important priority in this fishery. These resource allocations were crucial in generating economic spinoffs in regions. As one of the managers of the Labrador Shrimp Company commented, "... the offshore licenses have been the blood that has flowed to keep the life in the company... but at the same time, if you didn't have the offshore licenses, it would be very, very difficult to continue operating" (Foley et al. 2015:395).

\section{Sustainable livelihoods}

The organizational mandates to support regional development and employment provide a crucial link between state allocation policy objectives and impacts on labor and livelihoods, a connection that seems more ephemeral in individual transferable quota systems. For example, as part of contractual agreements with owners of offshore trawlers, the Torngat Co-op was able to use its offshore shrimp license as leverage to secure commitments from offshore vessel owners to create 16 crew positions for local residents. It has also supported approximately 100 jobs annually in both inshore harvesting and processing plants with estimates of CAD \$50 million and CAD\$34 million in paid income since the co-op was established (Torngat Co-op 2012, 2016). Similarly, for the Labrador Shrimp Company, its two offshore licenses not only generated up to approximately CAD $\$ 30$ million in royalty payments over the years but also enabled the organization to secure employment for people from the region with their offshore vessel owner partners and to invest in three processing plants that employ hundreds of people (Foley et al. 2015). Although sustainable livelihoods are conceptually problematic in a context of market dependency, auditing social development requires an appreciation of the social relations of, and knowledge about, labor and livelihood conditions, particularly in areas with limited alternative labor and livelihood opportunities.

\section{Developmental phase 2: new beneficiaries, 1997 to 2007}

\section{Distribution of access and benefits}

Auditing social development in fisheries requires an appreciation of diverse actual and potential access principles and mechanisms. Until the late 1990s, offshore sector license holders were the only commercial fishing actors with formal access to northern shrimp, with licenses capped at 17 by DFO in 1990 and a total allowable catch growing to 37,600 tonnes by 1996 . During the early 1990 s, two key events fundamentally reshaped the Canadian state's approach to distributing allocations to northern shrimp. First, the collapse of northern cod stocks from the late 1980s and the subsequent fishing moratorium imposed in 1992 led to a massive displacement of harvesters and processing workers across Atlantic Canada, but especially in NL. Second, the period from the late 1980s and early 1990s coincided with rapid growth in the biomass of northern shrimp stocks (Mather 2013). Given the effects of the cod moratorium on NL's fishery and the lobbying by the inshore sector interests such as FFAW-Unifor union to secure access to the growing northern shrimp resource for its struggling fisher and processing worker members, the Government of Canada decided to allocate northern shrimp to a "new" ${ }^{[1]}$ inshore owner-operator fleet that eventually supported $>300$ owner-operator inshore vessels and the development of 13 inshore shrimp processing plants in NL. The decision was heavily influenced by the adjacency principle noted above (Foley et al. 2015). Although offshore license holders initially resisted the idea of distributing access to new participants, the offshore sector also benefited from the health of northern shrimp stocks and was allocated additional quotas. Importantly, the DFO also granted various local or regional organizations Special Allocations, which were generally used to secure royalties from offshore vessel owners contracted to catch the allocations. Thus, inshore owner-operator permits and licenses and Special Allocations joined offshore licenses as new institutional mechanisms for distributing access and benefits in the northern shrimp fishery.

Regional economic benefits to community

The growth of the inshore fleet and associated growth in shrimp processing factories around NL helped mitigate widespread impacts of the 1992 and other groundfish moratoria on some companies, owner-operators, crews, processing plant workers, and communities (Foley et al. 2015). More than 300 licensed owner-operator inshore shrimp vessels in Canada secured access to shrimp by the 2000s, each employing five or six crew members, and most concentrated in Shrimp Fishing Area 6 adjacent to northeast Newfoundland and southeast Labrador (Gardner Pinfold Consulting Economists 2006, Government of Newfoundland and Labrador 2012). By 2005, onshore processing plants had increased from 3 to 13 , generating much needed employment opportunities and other economic spinoffs.

The idea of distributing Special Allocations, rather than offshore fishing licenses, to organizations was inspired in part by the royalty model employed by the Torngat Co-op and the Labrador Shrimp Company, providing DFO an option to distribute access for social development purposes without adding additional fishing capacity. DFO's first Special Allocation was 3000 tonnes designated to "the communities from Big Brook to Goose Cove" on the northern tip of the Northern Peninsula of NL (Foley et al. 2015). To manage the allocation, people in the region created a multistakeholder, nonprofit organization called St. Anthony Basin Resources Inc. (hereafter SABRI), with a volunteer board representing processing workers, fish harvesters, and regional development and municipal interests in the designated region. Guided by a mandate to support development opportunities in the region, SABRI partnered with a corporate offshore licence holder to build and operate a multipurpose processing plant in St. Anthony and engaged in a variety of regional and community development initiatives. These initiatives include supporting the development of a cold storage facility and distributing community development grants. By 2010, SABRI had invested CAD $\$ 190,000$ in student scholarships, CAD $\$ 500,000$ in community recreation centers and cultural functions, and CAD $\$ 194,000$ in local businesses (Foley and Mather 2016). 
DFO granted smaller Special Allocations to the Fogo Island Coop and the Nunatsiavut Government. Fogo Island Co-op generated royalties from its Special Allocation, which supported its CAD \$6 million investment in developing a shrimp processing plant for its fish harvester owners to land shrimp as the inshore shrimp fishery commenced (Fogo Island Co-op 2016). The Special Allocation, coupled with the development of inshore shrimp harvesting and processing capacity, enabled Fogo Island Co-op to build on its role as an economic anchor for the Fogo Island region. As an example of the impact of the shrimp fishery on the regional political economy, Fogo Island Co-op paid CAD $\$ 300,000$ in municipal taxes, CAD $\$ 200,000$ in provincial and federal taxes, and an estimated CAD $\$ 4$ million in income tax deductions in 2015 (Fogo Island Co-op 2016). This finding is consistent with other regions in the province of $\mathrm{NL}$, where municipal revenue facilitated local development and infrastructure provision in areas such as water systems, stores, gas stations, and recreation centres (Keenan and Carruthers 2015). In the early 2000s, the Labrador Inuit Association successfully lobbied for a Special Allocation, which the DFO acknowledged, granting the group a 510 tonne quota. The Indigenous association, which was replaced by the Nunatsiavut Government in 2005, also developed innovative ways to translate allocations of shrimp into employment and livelihood opportunities.

\section{Sustainable livelihoods}

The distribution of access to the inshore owner-operator sector and the distribution of Special Allocations to communityembedded organizations had significant social impacts in the regions of Fogo Island, the Northern Peninsula, and Nunatsiavut. Like the Torngat Co-op and the Labrador Shrimp Company, SABRI used its allocation to secure agreement from its offshore partner to employ $>20$ fishermen from the region annually in the offshore sector (Foley et al. 2015). The processing plant and cold storage operations that SABRI helped establish in St. Anthony employed between 100 and 200 people annually by the early 2000 s (Foley et al. 2015, Pisces Consulting 2015). The shrimp plant developed by Fogo Island Co-op benefited its fish harvesters significantly because it opened a local port to land and sell shrimp and it created employment in the processing plant for $>100$ people. Given that the Special Allocation royalty funds supported not just the shrimp-related activities but also the broader, multispecies harvesting and processing operations of the co-op, shrimp directly and indirectly supported approximately 550 harvesters or workers and 180 plant workers, with payrolls of CAD \$27 million and CAD\$5 million, respectively (Fogo Island Co-op 2016).

The Nunatsiavut Government also used its Special Allocation to expand labor and livelihood opportunities, usually in collaboration with the Torngat Co-op. Although the Nunatsiavut Government initially used its Special Allocation to generate royalties from offshore partners, it later reorganized its Special Allocation under a DFO-sanctioned communal license program. The communal license system allowed Inuit beneficiaries of the Labrador Inuit Land Claim Agreement to fish in the inshore sector under the authority of a communal license. Registered beneficiaries of the land claim agreement who are also inshore fish harvesters are eligible to receive portions of the Special Allocation. During the study period, the Nunatsiavut Government designated up to 14 beneficiaries who operate between seven and nine vessels and who were required to hire a minimum of one additional crew member, resulting in as many as 32 people employed annually (Foley et al. 2017). These efforts by the Nunatsiavut Government complemented the Torngat Coop's efforts to create employment opportunities for people from the region on offshore vessels, employment in fish plants, opportunities for inshore harvesters for shrimp and other species, and the development of new fisheries (e.g., crab and turbot).

\section{Developmental phase 3: resource decline and dispossession, 2011} to present

\section{(Re) distribution of access and benefits}

The case of the northern shrimp fishery points to the challenge of auditing distributive decisions in periods of rapid socialecological change. Since 2011, the distribution of access and benefits have been in flux, including significant quota reductions and associated social dislocation and uncertainty and anxiety about future change. While northern shrimp stocks increased rapidly from the early $1990 \mathrm{~s}$, by the end of the $2000 \mathrm{~s}$, a combination of fishing pressure and environmental change resulted in reduced shrimp stocks in some areas, particularly adjacent to NL. DFO began cutting quotas in response to these changes, and initially used a controversial last-in, first-out (LIFO) policy to distribute reductions. The origins of the policy are a matter of debate, but through this approach, quotas were initially cut more severely for inshore owner-operator harvesters relative to offshore licence holders because inshore interests gained access later than offshore interests.

The LIFO approach came under severe criticism from some interests, particularly the NL-based inshore sector. Inshore interests argued forcefully that the LIFO policy neglected longstanding policies of adjacency and compromised the future sustainability of coastal communities (Keenan and Carruthers 2015), also pointing to the removal of Fogo Island Co-op's Special Allocation in 2011 (Foley et al. 2015). DFO's use of the LIFO policy to allocate and distribute reductions triggered significant disputes and social tension, and strained relationships among the major interests in the fisheries sector. Two DFO-sponsored independent reviews, the Northern Shrimp Independent Review 2012 (http://www.dfo-mpo.gc.ca/fm-gp/peches-fisheries/reportsrapports/eap-pce/index-ns-cn-eng.htm) and a Ministerial Advisory Panel for the External Review of the DFO's LIFO policy for northern shrimp 2016 (http://www.dfo-mpo.gc.ca/fm-gp/pechesfisheries/comm/shrimp-crevette/lifo-report-rapport-deps-eng.htm), were completed, the latter resulting in the elimination of LIFO policy.

The LIFO policy dispute highlights some challenges of auditing social development in contexts of intrafishery fragmentation, conflict, and resource dispossession as different interests struggle to maintain access to a changing resource. Some of the contention in the northern shrimp fishery is embedded in historical conflicts over resource access and different conceptions of responsible and ethical production, often one that distinguishes small-scale, community-based modes of production from more industrial, capital-intensive modes of production. Complicating the auditing of such situations is the integration of offshore-inshore interests in Torngat Co-op, Labrador Shrimp Company, SABRI, Fogo Island Co-op, and the Nunatsiavut Government. To generate capital and employment benefits for inshore fishery development, 
all of these organizations have used offshore licenses or Special Allocations to generate royalties from corporate, vertically integrated offshore fishing companies.

\section{(Loss of) regional economic benefits to community}

Reduced shrimp quotas have resulted in the closure of onshore shrimp processing plants in NL, and more plants may close because of these unfavorable conditions (Keenan and Carruthers 2015, Pisces Consulting 2015). In recent years, shrimp plants in Jackson's Arm, Clarenville, and Twillingate closed, putting hundreds of people out of work (Keenan and Carruthers 2015). Declines in shrimp stocks and fishing quotas have resulted in inadequate funds for providing and maintaining municipal infrastructure and essential services in some communities and regions. For instance, the closure of the Jackson's Arm shrimp plant undermined community water supplies (Keenan and Carruthers 2015). Although shrimp plants remain in operation in Charlottetown (owned by the Labrador Shrimp Company), St. Anthony (partly owned by SABRI), and on Fogo Island (owned by Fogo Island Co-op), each is struggling with reduced supply and has reduced its workforce. All of these plants are vulnerable to closure. Changing resource access dynamics may cause both inshore and offshore sectors to take actions such as deliberate closing, merging licenses, moving into other fishing ventures, or declaring bankruptcy (Pisces Consulting 2015).

\section{(Un) sustainable livelihoods}

The reduction of access to shrimp since 2011 may have resulted in CAD\$6 million and CAD \$4.2 million reductions in income for inshore and onshore processing activities, respectively, in NL (Government of Newfoundland and Labrador 2012, Newfoundland and Labrador Independent Fish Harvesters Association Inc. 2016). As indicated in the quotations at the beginning of this article, further quota declines will potentially have devastating consequences for the inshore harvesting and processing sectors and reduce their ability to support local employment and livelihoods. As indicated, the northern shrimp fishery directly and indirectly supports the employment and incomes of hundreds of individuals in our case study regions, each having populations of 2000 to 4000 people. Declines in shrimp stocks and quotas will also affect royalty payments from the offshore license holders (Canadian Association of Prawn Producers 2016) and jobs in the offshore sector, which support some individuals in those regions.

\section{DISCUSSION AND CONCLUSION}

The MSC is formally transparent about its focus on sustaining fish stocks and marine ecosystems. Its standard for "sustainable and well managed fisheries" does not include a comprehensive category of social criteria and indicators, and therefore, it is not surprising that the third-party assessment of the northern shrimp fishery and other MSC-certified fisheries do not document various social dimensions of fisheries. Nevertheless, the exclusion of social considerations is problematic in a context of growing worldwide interest in integrated and holistic social-ecological resource management and assessment and recent well-publicized seafood scandals that have captured the attention of media outlets and nongovernmental organizations (NGOs). By examining a case of an MSC-certified fishery through a lens of social development, we hope to contribute to growing global discussions about challenging narrowly neoliberal rationalities by integrating social and moral economy questions into fisheries management generally (Pinkerton and Davis 2015, Pinkerton 2017) and in sustainability assessments for fisheries and seafood specifically. Indeed, the lack of formal tracking and assessment of social indicators in both public and nongovernmental fisheries governance bodies has motivated industry, NGOs, and scientists (social and natural) to become "expertised" (Ponte 2009). This is in part why the CFRN sought to develop an integrated socialecological evaluation framework for sustainable fisheries (Stephenson et al. 2018b).

We understand the growing interest in addressing the social question in fisheries governance through alternative assessment frameworks, including the CFRN's sustainability assessment framework, as technologies of government for alternative socialecological environmentalities that put social development and social justice at the forefront of sustainability questions. The use of such technologies of government enables managers, policy makers, NGOs, communities, regions, companies, and workers to gain insight into the often-obscured social objectives and social effects of fisheries governance (Brooks et al. 2015). We think that this work will help decision-making processes to address social development "issues of access and benefits distribution both now and in the future... [because]... the well-being and survival of coastal communities depends on access and related benefits, particularly under changing environmental conditions" (Bennett et al. 2018:191). Our purpose was not to develop a systematic assessment of the northern shrimp fishery using detailed criteria and indicators in CFRN's technology of government, but rather to identify a range of historically significant social development dimensions of the fishery that are not considered in MSC assessments, specifically areas of (1) distribution of access and benefits, (2) regional economic benefits, and (3) labor and livelihoods. Decades of DFO allocation decisions in the northern shrimp fishery, though complex, dynamic, and sometimes contradictory, were driven by general principles of prioritizing development benefits for adjacent coastal communities. People living in the case study regions who engaged in the shrimp fishery benefited from social development-oriented rationalities of state allocations, but also, importantly, from the social purpose rationalities of allocation holders in their regions, i.e., Torngat Co-op, Labrador Shrimp Company, SABRI, Fogo Island Co-op, and the Nunatsiavut Government. The decisions of these organizations to distribute resource benefits and support regional development and local livelihoods depended, in turn, on the presence of inshore owner-operator harvesting and processing sectors in which they invested. Driven in part by distributive rationalities, these decisions and their social and economic effects provide new knowledge for building alternative social-ecological environmentalities. Any alternative social-ecological environmentality must contend, however, with other challenging realities that are difficult to capture in technical-oriented audits. The social development dimensions of fisheries "sustainability," including contested conceptions of sustainable and dignified labor and livelihoods, are also contingent on social and market relations in specific social and political contexts, including structural forces such as capitalist international trade.

Our analysis calls for the promotion of social-ecological environmentalities in the plural and asks researchers to examine further the different rationalities and technologies manifesting in 
the proliferation of assessments and auditing frameworks for fisheries specifically and natural resources more generally. Ultimately, the inclusion of more explicit principles of social sustainability into assessment frameworks and eco-certifications may not have a greater direct effect on social development (Boström et al. 2015a). We are not, therefore, suggesting that the development of a socially attentive assessment process will "solve" the ecological and social problems facing the northern shrimp fishery specifically or the problems of fisheries managerialism (Bavington 2010) more generally. Social-oriented auditing cannot transcend politics or render ethically challenging decision making into a technical process. Even if auditing frameworks are used as decision-support tools in contexts receptive to progressive fisheries governance, decision makers will continue to deal with contradictory objectives and trade-offs. By integrating social development into sustainability assessment in our analysis, we also acknowledge that we are engaged in and legitimizing the practice of "rendering technical," that is, creating a new representation of the domain to be governed. Our analysis suggests, however, the value in acknowledging political and strategic opportunities for developing alternative assessment tools and indicators in the struggle over governing while also recognizing there are limits to the use of auditing approaches for triggering fundamental change. Our practice of rendering technical or, more accurately, rendering visible, is not one of rendering nonpolitical. We seek not to recast political questions as technical questions but instead recast technical frameworks as political by inserting social development information and knowledge derived from labor and community-oriented fieldwork into technical frameworks. Indeed, "integrating the social and the environmental in policy, administration, and management will require a long-term learning process" (Boström et al. 2015b:152). In the short term, we suggest that the clearest benefit of the move to social-ecological envrionmentalities consists of social and political learning in support of other collaborative efforts and collective struggles to construct and perform new sustainable economies with alternative ethical orientations. In the long term, assessment and auditing frameworks will count as one among many factors in the struggle to create sustainable and socially just fisheries.

${ }^{[1]}$ An inshore northern shrimp sector has existed in the Gulf of St. Lawrence since the late 1960s. Strictly speaking, the inshore sector that emerged in the late 1990s and operated along the northeast coast of Newfoundland and along the Labrador coast was not new.

Responses to this article can be read online at: http://www.ecologyandsociety.org/issues/responses. php/10382

\section{Acknowledgments:}

We thank Rob Stephenson and Marc Allain for their leadership in the Canadian Fisheries Research Network; the Harris Centre at Memorial University of Newfoundland; David Decker and the Fish, Food and Allied Workers-Unifor union; Jamie Snook, the Torngat
Secretariat, and the Torngat Joint Fisheries Board; the Nunatsiavut Government; the Torngat Fish Producers Co-operative Society Ltd.; the Fogo Island Co-op; St. Anthony Basin Resources Incorporated; and all the interview participants who volunteered their time. Any errors are our own.

\section{LITERATURE CITED}

Agrawal, A. 2005. Environmentality: technologies of government and the making of subjects. Duke University Press, Durham, North Carolina, USA.

Bartlett, G., and A. Kelland. 2017. No charges as protestors leave DFO HQ after smashing window, breaking into building. $C B C$ News 07 April 2017. [online] URL: https://www.cbc.ca/news/ canada/newfoundland-labrador/dfo-protest-union-shrimp-cuts-1.4060038

Bavington, D. 2010. From hunting fish to managing populations: fisheries science and the destruction of Newfoundland cod fisheries. Science as Culture 19(4):509-528. https://doi. org/10.1080/09505431.2010.519615

Bennett, N. J., M. Kaplan-Hallam, G. Augustine, N. Ban, D. Belhabib, I. Brueckner-Irwin, A. Charles, J. Couture, S. Eger, L. Fanning, P. Foley, A. M. Goodfellow, L. Greba, E. Gregr, D. Hall, S. Harper, B. Maloney, J. McIsaac, W. Ou, E. Pinkerton, D. Porter, R. Sparrow, R. Stephenson, A. Stocks, U. R. Sumaila, T. Sutcliffe, and M. Bailey. 2018. Coastal and Indigenous community access to marine resources and the ocean: a policy imperative for Canada. Marine Policy 87:186-193. https://doi.org/10.1016/j. marpol.2017.10.023

Boström, M., A. M. Jönsson, S. Lockie, A. P. J. Mol, and P. Oosterveer. 2015a. Sustainable and responsible supply chain governance: challenges and opportunities. Journal of Cleaner Production 107:1-7. https://doi.org/10.1016/j.jclepro.2014.11.050

Boström, M., Å. C. Vifell, M. Klintman, L. Soneryd, K. T. Hallström, and R. Thedvall. 2015b. Social sustainability requires social sustainability: procedural prerequisites for reaching substantive goals. Nature and Culture 10(2):131-156. https://doi. org/10.3167/nc.2015.100201

Brooks, K., J. Schirmer, S. Pascoe, L. Triantafillos, E. Jebreen, T. Cannard, and C. M. Dichmont. 2015. Selecting and assessing social objectives for Australian fisheries management. Marine Policy 53:111-122. https://doi.org/10.1016/j.marpol.2014.11.023

Canadian Association of Prawn Producers. 2016. Submission to the Ministerial Advisory Panel for the LIFO review. Canadian Association of Prawn Producers, Manotick, Canada. [online] URL: http://www.dfo-mpo.gc.ca/fm-gp/peches-fisheries/comm/ shrimp-crevette/pdf/CAPP $\% 20$ submission.pdf

CBC News. 2016. 'About survival of our communities:' shrimp protesters tell Ottawa to choose local over 'foreign interests'. $C B C$ News 03 March 2016. [online] URL: http://www.cbc.ca/news/ canada/newfoundland-labrador/shrimp-quota-rally-dfo-lifopolicy-1.3474006

Djama, M., E. Fouilleux, and I. Vagneron. 2011. Standardsetting, certifying and benchmarking: a governmentality approach to sustainability standards in the agro-food sector. Pages 184-209 in S. Ponte, P. Gibbon, and J. Vestergaard, editors. Governing through standards: origins, drivers and limitations. Palgrave Macmillan, London, UK. 
Ensing, C. 2016. Shrimp fishery 'crisis' eye-opener for Gander chamber of commerce. CBC News 18 May 2016. [online] URL: https://www.cbc.ca/news/canada/newfoundland-labrador/shrimpfishery-crisis-impact-on-gander-larger-towns-1.3587331

Fletcher, R. 2010. Neoliberal environmentality: towards a poststructuralist political ecology of the conservation debate. Conservation and Society 8(3):171-181. [online] URL: http://dx. doi.org/10.4103/0972-4923.73806

Fletcher, R. 2017. Environmentality unbound: multiple governmentalities in environmental politics. Geoforum 85:311-315. https://doi.org/10.1016/j.geoforum.2017.06.009

Fogo Cooperative Society Ltd (Fogo Island Co-op). 2016. Position regarding DFO's last-in-first-out policy as it applies to the northern shrimp fishery. Submitted to the Ministerial Advisory Panel. Fogo Cooperative Society, Seldom, Canada. [online] URL: http://www.dfo-mpo.gc.ca/fm-gp/peches-fisheries/comm/shrimpcrevette/pdf/Fogo $\% 20$ Response $\% 20$ to $\% 20$ MAP JUNE $\% 203$ FINAL. $\underline{\mathrm{PDF}}$

Foley, P. 2012. The political economy of Marine Stewardship Council certification: processors and access in Newfoundland and Labrador's inshore shrimp industry. Journal of Agrarian Change 12(2-3):436-457. https://doi.org/10.1111/j.1471-0366.2011.00344. $\underline{\mathrm{X}}$

Foley, P., and C. Mather. 2016. Making space for community use rights: insights from "community economies" in Newfoundland and Labrador. Society and Natural Resources 29(8):965-980. http://dx.doi.org/10.1080/08941920.2015.1089611

Foley, P., and C. Mather. 2018. Ocean grabbing, terraqueous territoriality and social development. Territory, Politics, Governance. https://doi.org/10.1080/21622671.2018.1442245

Foley, P., C. Mather, R. Morris, and J. Snook. 2017. Change shrimp allocation policies and regional development under conditions of environmental change: insights for Nunatsiavutimmuit. Prepared for the Leslie Harris Centre of Regional Policy and Development. Memorial University of Newfoundland, St John's, Canada. [online] URL: https://www.mun.ca/harriscentre/reports/ FOLEY ARF 15 16.pdf

Foley, P., C. Mather, and B. Neis. 2013. Fisheries allocation policies and regional development: successes from the Newfoundland and Labrador shrimp fishery. Prepared for the Leslie Harris Centre of Regional Policy and Development. Memorial University of Newfoundland, St John's, Canada. [online] URL: https://www. mun.ca/harriscentre/reports/arf/2011/11-12-ARF-Final-Mather.pdf

Foley, P., C. Mather, and B. Neis. 2015. Governing enclosure for coastal communities: social embeddedness in a Canadian shrimp fishery. Marine Policy 61:390-400. https://doi.org/10.1016/j. marpol.2014.11.009

Foley, P., and B. McCay. 2014. Certifying the commons: ecocertification, privatization, and collective action. Ecology and Society 19(2):28. http://dx.doi.org/10.5751/ES-06459-190228

Foucault, M. 2008. The birth of biopolitics: lectures at the Collège de France, 1978-79. M. Senellart, editor. Palgrave MacMillan, Basingstoke, UK.
Gardner Pinfold Consulting Economists. 2006. Profile of the Atlantic shrimp industry. Submitted to the Atlantic Council of Fisheries and Aquaculture Ministers Task Group on Northern Shrimp. Gardner Pinfold Consulting Economists, Halifax, Canada. [online] URL: http://epub.sub.uni-hamburg.de/epub/ volltexte/2013/17735/pdf/sr_rc_e.pdf

Government of Newfoundland and Labrador. 2012. Government of Newfoundland and Labrador's submission to the review of the allocations within the northern shrimp fishery. Government of Newfoundland and Labrador, St. John's, Canada. [online] URL: http://www.dfo-mpo.gc.ca/fm-gp/peches-fisheries/reports-rapports/ eap-pce/documents/nl-eng.pdf

Hardin, G. 1968. The tragedy of the commons. Science 162:1243-1248. http://dx.doi.org/10.1126/science.162.3859.1243

Hughes, A. 2001. Global commodity networks, ethical trade and governmentality: organizing business responsibility in the Kenyan cut flower industry. Transactions of the Institute of British Geographers 26(4):390-406. https://doi.org/10.1111/1475-5661.00031

Jensen, C. B., and B. R. Winthereik. 2013. Monitoring movements in development aid: recursive partnerships and infrastructures. MIT Press, Cambridge, Massachusetts, USA.

Keenan, R., and E. H. Carruthers. 2015. The northern shrimp fishery: the socio-economic importance of maintaining adjacency in allocation decisions. Fish, Food and Allied Workers-Unifor, Corner Brook, Canada. [online] URL: http://ffaw.nf.ca/sites/ffaw. nf.ca/files/Northern $\% 20$ Shrimp $\% 20$ Allocations $\% 20$ and $\% 20$ Impacts. pdf

Kittinger, J. N., L. C. L. Teh, E. H. Allison, N. J. Bennett, L. B. Crowder, E. M. Finkbeiner, C. Hicks, C. G. Scarton, K. Nakamura, Y. Ota, J. Young, A. Alifano, A. Apel, A. Arbib, L. Bishop, M. Boyle, A. M. Cisneros-Montemayor, P. Hunter, E. Le Cornu, M. Levine, R. S. Jones, J. Z. Koehn, M. Marschke, J. G. Mason, F. Micheli, L. McClenachan, C. Opal, J. Peacey, S. H. Peckham, E. Schemmel, V. Solis-Rivera, W. Swartz, and T. 'A. Wilhelm. 2017. Committing to socially responsible seafood. Science 356(6341):912-913. https://doi.org/10.1126/science.aam9969

Konefal, J. 2013. Environmental movements, market-based approaches, and neoliberalization: a case study of the sustainable seafood movement. Organization and Environment 26(3):336-352. https://doi.org/10.1177/1086026612467982

Labrador Fishermen's Union Shrimp Company Limited (Labrador Shrimp Company). 2016. Submission to the Ministerial Advisory Panel (MAP) on the last in, first out (LIFO) policy on the northern shrimp fishery. Labrador Fishermen's Union Shrimp Company, L'Anse-au-Loup, Canada. [online] URL: http://www.dfo-mpo.gc.ca/fm-gp/peches-fisheries/comm/ shrimp-crevette/pdf/LFUSCL $\% 20$ Submission $\% 20$ to $\% 20$ the $\% 20$ Panel $\%$ 20June $\% 203 \% 202016$.pdf

LeBaron, G., and J. Lister. 2015. Benchmarking global supply chains: the power of the 'ethical audit' regime. Review of International Studies 41(5):905-924. http://dx.doi.org/10.1017/ $\underline{\mathrm{S} 0260210515000388}$

LeBaron, G., J. Lister, and P. Dauvergne. 2017. Governing global supply chain sustainability through the ethical audit regime. Globalizations 14(6):958-975. https://doi.org/10.1080/14747731.$\underline{2017.1304008}$ 
Mather, C. 2013. From cod to shellfish and back again? The new resource geography and Newfoundland's fish economy. Applied Geography 45:402-409. https://doi.org/10.1016/j.apgeog.2013.06.009

Newfoundland and Labrador Independent Fish Harvesters Association. 2016. Rationale against continuation of LIFO policy in the northern shrimp fishery. Submitted to Ministerial Advisory Panel. Newfoundland and Labrador Independent Fish Harvesters Association, Brigus, Canada. [online] URL: http:// www.dfo-mpo.gc.ca/fm-gp/peches-fisheries/comm/shrimp-crevette/ pdf/NLIFHA $\% 20$ LIFO $\% 20$ PAPER June $\% 203$ FINAL.PDF

Ostrom, E. 1990. Governing the commons: the evolution of institutions for collective action. Cambridge University Press, Cambridge, UK.

Ostrom, E., J. Burger, C. B. Field, R. B. Norgaard, and D. Policansky. 1999. Revisiting the commons: local lessons, global challenges. Science 284(5412):278-282. http://dx.doi.org/10.1126/ science.284.5412.278

Parlee, C. E. 2016. Resolving conflict over risk management in the marine environment: strengthening governance institutions. Dissertation. University of New Brunswick, Fredericton, Canada. [online] URL: https://unbscholar.lib.unb.ca/islandora/ object/unbscholar\%3A7858/

Parlee, C. E., and M. G. Wiber. 2014. Institutional innovation in fisheries governance: adaptive co-management in situations of legal pluralism. Current Opinion in Environmental Sustainability 11:48-54. https://doi.org/10.1016/j.cosust.2014.09.012

Pinkerton, E. 2017. Hegemony and resistance: disturbing patterns and hopeful signs in the impact of neoliberal policies on smallscale fisheries around the world. Marine Policy 80:1-9. https://doi. org/10.1016/j.marpol.2016.11.012

Pinkerton, E., and R. Davis. 2015. Neoliberalism and the politics of enclosure in North American small-scale fisheries. Marine Policy 61:303-312. https://doi.org/10.1016/j.marpol.2015.03.025

Pisces Consulting. 2015. Final report: socio-economic impacts of shrimp quota reductions in Newfoundland and Labrador. Submitted to Newfoundland and Labrador Department of Fisheries and Aquaculture. Pisces Consulting, Hammonds Plains, Canada. [online] URL: http://www.fishaq.gov.nl.ca/publications/pdf/ Socio Economic Impacts of Shrimp Quota Reductions.pdf

Ponte, S. 2008. Greener than thou: the political economy of fish ecolabeling and its local manifestations in South Africa. World Development 36(1):159-175. https://doi.org/10.1016/j. worlddev.2007.02.014

Ponte, S. 2009. From fishery to fork: food safety and sustainability in the 'virtual' knowledge-based bio-economy (KBBE). Science as Culture 18(4):483-495. https://doi.org/10.1080/09505430902873983

Potts, J., A. Wilkings, M. Lynch, and S. McFatridge. 2016. State of sustainability initiatives review: standards and the blue economy. International Institute for Sustainable Development, Winnipeg, Canada. [online] URL: http://www.iisd.org/sites/default/files/ publications/ssi-blue-economy-2016.pdf

Powles, H., J. Angel, and R. Blyth-Skyrne. 2016. MSC sustainable fisheries certification: Canada northern and striped shrimp fishery. Acoura Marine Ltd. public certification report. Marine
Stewardship Council, London, UK. [online] URL: https:// fisheries.msc.org/en/fisheries/canada-northern-and-striped-shrimp/ a, a,assessments

Shore, C., and S. Wright. 2015. Audit culture revisited: rankings, ratings, and the reassembling of society. Current Anthropology 56 (3):421-444. https://doi.org/10.1086/681534

Stephenson, R. L., S. Paul, M. Wiber, E. Angel, A. J. Benson, A. Charles, O. Chouinard, M. Clemens, D. Edwards, P. Foley, L. Jennings, O. Jones, D. Lane, J. McIsaac, C. Mussells, B. Neis, B. Nordstrom, C. Parlee, E. Pinkerton, M. Saunders, K. Squires, and U. R. Sumaila. 2018a. Evaluating and implementing socialecological systems: a comprehensive approach to sustainable fisheries. Journal of Fish and Fisheries 19(5):853-873. https://doi. org/10.1111/faf.12296

Stephenson, R. L., M. Wiber, S. Paul, E. Angel, A. Benson, A. Charles, O. Chouinard, D. Edwards, P. Foley, D. Lane, J. McIsaac, B. Neis, C. Parlee, E. Pinkerton, M. Saunders, K. Squires, and U. R. Sumaila. 2018b. Integrating diverse objectives for sustainable fisheries in Canada. Canadian Journal of Fisheries and Aquatic Sciences.. https://doi.org/10.1139/cjfas-2017-0345

Symes, D., and J. Phillipson. 2009. Whatever became of social objectives in fisheries policy? Fisheries Research $95(1): 1-5$. https:// doi.org/10.1016/i.fishres.2008.08.001

Torngat Fish Producers Co-operative Society Ltd. (Torngat Coop). 2012. Northern shrimp independent review submission received by Ernst \& Young, dated 29 February 2012. Torngat Co-op, Happy Valley-Goose Bay, Canada. [online] URL: http://www.dfo-mpo. gc.ca/fm-gp/peches-fisheries/reports-rapports/eap-pce/documents/ torngatfpcoop-eng.pdf

Torngat Fish Producers Co-operative Society Ltd. (Torngat Coop). 2016. Submission to the Ministerial Advisory Panel on the last in, first out policy in the northern shrimp fishery. Torngat Co-op, Happy Valley-Goose Bay, Canada. [online] URL: http://www. dfo-mpo.gc.ca/fm-gp/peches-fisheries/comm/shrimp-crevette/pdf/ Torngat $\% 20$ Fish $\% 20$ Producers $\% 20$ Co-op $\% 20-\% 20$ Submission $\%$ 20to $\% 20$ MAP $\% 20$ on $\% 20$ LIFO.pdf

Urquhart, J., T. Acott, and M. Zhao. 2013. Introduction: social and cultural impacts of marine fisheries. Marine Policy 37:1-2. https://doi.org/10.1016/j.marpol.2012.04.007

Wood, S. 2012. The International Organization for Standardization. Pages 81-94 in D. Reed, P. Utting, and A. Mukherjee-Reed, editors. Business regulation and non-state actors: Whose standards? Whose development? Routledge, London, UK. 